\title{
AGNOSTISISME MODERN
}

\author{
Faisal \\ faisal@uinib.ac.id \\ Universitas Islam Negeri Imam Bonjol Padang
}

\begin{abstract}
Abstrak : Pemikiran tentang Tuhan sebagai tema utama dalam agama, mengalami dinamika sepanjang sejarah manusia. Pencarian Tuhan ternyata tidak berhenti ketika konsep Teisme memberi jawaban dengan berbagai argumentasi. Salah satu paham yang muncul kemudian adalah agnostisisme yang pada prinsipnya memandang bahwa manusia tidak bisa memberikan jawaban mengenai apakah Tuhan ada atau tidak. Bagi penganut paham ini, jawaban ada atau tidak, memiliki nilai yang sama karena eksistensi Tuhan tidak bisa dibuktikan secara ilmu pengetahuan empiris dan positivistik. Tulisan ini akan membahas paham agnostik ini, baik tentang pengertian, akar pemahaman, maupun tentang kaitannya dengan sains.
\end{abstract}

Kata Kunci : Agnostisisme, Teisme, Pengetahuan Empiris dan Positifistik

\section{A. PENDAHULUAN}

Dalam konteks manusia sebagai makhluk beragama (homo religious), tentunya pembicaraan tentang Tuhan sama tuanya dengan umur manusia. Hal ini lantaran -seperti disebut Rudolf Otto dalam The Idea of the Holly, ${ }^{1}$ bahwa rasa tentang Yang Ghaib (numinous) adalah basic to religion. Karen Armstrong dalam karya besarnya, A History of God, The 4000- Year Quest of Judaism, Christianity and Islam, menunjukkan secara historis kisah pencarian Tuhan oleh umat manusia sejak 14.000 tahun lalu. $^{2} \quad$ Armstrong tidak saja membeberkan adanya semacam dinamika persepsi tentang Tuhan oleh manusia sepanjang sejarahnya, tetapi juga pada akhirnya mempertanyakan persoalan ketuhanan dalam perkembangan pemikiran manusia di masa-masa mendatang.

1 Seperti dikutip Karen Armstrong, A History of God, The 4000- Year Quest of Judaism, Christianity and Islam, (New York: Alfred A. Knopf, 1993), hal. 4-5. hal. 4.
Di antara tantangan yang dihadapi agama -khususnya perbincangan tentang Tuhan- adalah ketika vis a vis dengan kecenderungan adanya dinamika perkembangan pemikiran manusia. Karena itu, Armstrong dalam karya di atas, mengungkapkan dalam bab khusus tentang bagaimana Tuhan para Filosof, Tuhan kaum Mistik, Tuhan para Reformis, bahkan Kematian Tuhan dan Adakah Masa Depan bagi Tuhan. Salah satu isu dalam konteks agama atau tepatnya Tuhan versus ilmu pengetahuan adalah ketika pandangan positivisme dan empirisme mendominasi pembuktian segala hal, termasuk Tuhan. Dalam konteks inilah agnostisisme modern, merupakan anak kandung dari pandangan tersebut. Ketika Tuhan tidak bisa dicandra secara empiris maka para penganut pandangan ini menangguhkan pembicaraan tentang Tuhan sehingga pertanyaan tentang apakah Tuhan ada atau tidak, tak akan bisa terjawab. Artinya, jikapun dijawab ada atau tidak ada, bagi mereka nilainya sama saja karena tidak bisa dibuktikan dengan argumentasi 
emipiris maupun positivistik. Persoalan inilah yang dideskripsikan pada tulisan sederhana ini.

\section{B. PENGERTIAN \\ BELAKANG}

Secara bahasa, agnostik berasal dari bahasa Yunani Kuno $\dot{\alpha}$ (a), yang berarti "tanpa", dan $\gamma \nu \tilde{\omega} \sigma 1 \varsigma$ (gnosis), yang berarti "pengetahuan". ${ }^{3}$ R.S. Sharma, dalam Encyclopedia International, mengemukakan pendapatnya tentang agnostisisme sebagai berikut:

Agnosticism from the Greek $a$, "not" and gignoskos "knowing" a term coined by Thomas Henry Huxley to denote his skeptical view of religion, and how used generally to refer to the attitude and tenets of those who believe that the existence of God cannot be known or proved, and who urge, therefore, a suspension of belief. $^{4}$

Pendapat Sharma di atas menjelaskan bahwa istilah yang diciptakan oleh Thomas Henry Huxley tersebut menunjukkan pandangan skeptis terhadap agama, serta merujuk pada sikap dan ajaran bahwa keberadaan Tuhan tidak bisa diketahui atau dibuktikan. Istilah agnostisime digunakan Huxley dalam pidatonya pada pertemuan masyarakat Metafisika

\footnotetext{
Lihat

https://id.wikipedia.org/wiki/Agnostisisme

4 R.S. Sharma, "Agnosticism", dalam Edward Humphrey (ed.),Encyclopedia International, (Columbia: Lexicon, Inc., 1978), vol. I, h. 157., seperti dikutip Muhammad Mastury, "Agnostisisme dan Skeptisime Suatu Analisis Perbandingan", dalam Jurnal AlJamiah No. 45 Th. 1991, hal. 84.
}

pada tahun $1869^{5}$ untuk menggambarkan filsafat yang menolak semua klaim pengetahuan tentang spiritual atau mistis. Meskipun demikian, sebenarnya istilah "gnosis" telah digunakan para pemimpin gereja Kristen awal untuk menggambarkan "pengetahuan spiritual".

Senada dengan pendapat Sharma di atas, Peter A. Angeles dalam Dictionary of Pholosophy menjelaskan bahwa terma tersebut berasal dari a dan gnostikios/ gignoskos/ gignoskein, yang berarti pengetahuan. Secara umum menurutnya agnostisisme dapat didefinisikan sebagai the belief that we cannot have knowledge of God and that is impossible to prove that God exist or does not exist. ${ }^{6}$ Menurut filsuf William L. Rowe, dalam arti sempit agnostisisme adalah pandangan bahwa akal manusia tidak mampu secara rasional membenarkan keyakinan tentang apa yang dilakukan Allah atau juga bahkan apakah Allah itu ada atau tidak. $^{7}$

Selanjutnya, dari sisi bahasa, agnostisisme juga merupakan kependekan dari antignostisisme. Gnostisisme, menurut A. Hardon adalah aliran yang memberi pengakuan tentang kemampuan mengetahui misteri alam semesta beserta apa yang terdapat di baliknya. Menurutnya,

\begin{tabular}{l}
\hline Thomas Henry \\
Huxley, \\
"Agnosticism". The Popular Science Monthly \\
(New York: D. Appleton \& Company, 1889), \\
hal. 768 Peter A. Angeles, Dictionary of \\
6 Pento \\
Philosophy, (New York: Bames \& Noble \\
Book, 1981), hal. 6. \\
Sebagaimana dikutip Wikipedia \\
Bahasa Indonesia dari Rowe, William L, \\
"Agnosticism". Di Edward Craig. Routledge \\
Encyclopedia of Philosophy, Taylor \& Francis, \\
1998.
\end{tabular}




\section{Majalah Ilmu Pengetahuan dan Pemikiran Keagamaan Tajdid,}

Vol. 20, No. 1, Juli 2017

aliran gnostisisme merupakan estafet dari aliran panteisme yang sudah eksis sebelum kedatangan agama Kristen. ${ }^{8}$ Sebagai antitesa dari gnostisisme, maka menurut aliran agnostisisme, adalah mustahil atau tidak mungkin manusia mempunyai pengetahuan tentang Tuhan. ${ }^{9}$

Thomas Henry Huxley (18251829), ${ }^{10}$ seperti disebutkan di atas, adalah tokoh yang dipandang sebagai pencetus terma agnostic. Huxley sendiri adalah seorang biolog Inggris yang terkenal dengan julukan "Bulldog Darwin" karena mendukung teori evolusi Charles Darwin. ${ }^{11}$ Bagi Huxley, agnostisisme bukanlah semacam kredo, tetapi merupakan pengertian yang lebih abstrak dan luas sebagai "metode penyelidikan skeptik, berbasis bukti".

8 Vide John A. Hardon, SJ., Pocket Chatolik Dictionary, (New York: A Division of Doubledaya and Company Inc., 1985), hal. 163.

${ }^{9}$ Lihat Romo Philipus Tule, SVD. (ed), Kamus Filsafat, (Bandung: Rosda Karya, 1995), hal. 6.

${ }^{10}$ Lihat Roger L. Shinn, "Agnostisisme" dalam George A. Cornish (ed.), Encyclopedia Americana, Internatimal Editio, (New York : Americana Corporation, 1970), vol. I, hal. 337.

${ }^{11}$ Ia juga dikenal sebagai ahli anatomi komparatif, seperti disebutkan Poulton E.B. dalam Charles Darwin and the Origin of Species.Lihat juga dalam https://www.britannica.com/biography/Thoma s-Henry-Huxley. Ia meneliti invertebrata dan mengklarifikasi hubungan antara kelompok yang sebelumnya tidak dipahami. Kemudian, ia juga meneliti vertebrata, terutama hubungan antara primata dan manusia. Hasil studinya dalam konteks ini antara lain, setelah membandingkan Archaeopteryx dengan Compsognathus, ia menyimpulkan bahwa burung berevolusi dari dinosaurus karnnivora yang kecil. Lihat https://id.wikipedia.org/wiki/Thomas_Henry_ Huxley.
12 Dalam kumpulan essainya, ia mengungkapkan kegelisahan intelektualnya ketika ia ragu terhadap berbagai aliran yang membahas tentang "Tuhan". Ia kemudian menetapkan dirinya sebagai "free thinker", di antara denominasi "an atheist, a theist or pantheist; a materiatst or an idealist; a Christian or free thinker" Sebagai antitesa, maka Huxley memproklamirkan dirinya tidak punya pengetahuan tentang Tuhan, berbeda dengan "gnostic" yang mengaku banyak mengerti. Dalam konteks ini yang dimaksud "gnostic" tidak lain adalah kalangan gereja pada waktu itu. ${ }^{13}$

Pengertian tentang agnostisisme ini terkait dengan istilah ephoce (Yunani $=$ perhentian) yang digunakan oleh kelompok skeptisisme untuk menunjukkan. pengertian penangguhan sementara dalam menilai sebuah kebenaran, kesalahan, kepercayaan atau ketidak percayaan pada ide-ide, hingga diperoleh ketentuan yang lebih jelas. Di samping itu juga berarti penyangkalan yang telah dipertimbangkan matang-matang atas sebuah pengertian menuju pengertian yang bebas dari prasangka. $^{14}$

Meski memiliki keterkaitan dengan skeptisisme, tetapi agnostisisme berbeda dalam beberapa hal dengan skeptisisme. Muhammad Mastury dalam tulisannya, "Agnostisisme dan Skeptisisme Suatu

12 Sebagaimana dikutip Wikipedia Bahasa Indonesia dari Aphorisms and Reflections. Kessinger Publishing. 2004 (reprint), hal. 41-42. Lihat Wikipedia

${ }^{13}$ James Hastings (ed.), Encyclopedia of Religion and Ethic, (New, York: Charles Seribner's Sons, tt), hal. 62-3. Gnostic dalam konteks ini adalah kalangan Gereja.

${ }^{14}$ Romo Philipus Tule, Kamus ... hal. 6 
Analisis Perbandingan" menjelaskan bahwa jika keduanya berangkat dari keraguan, maka keraguan pada skeptic terletak pada keraguan terhadap "obyek pengetahuan", sementara keraguan agnostic terletak pada keraguan terhadap "subyek yang mengetahui”. Karena itu menurut Mastury, keraguan skeptic mudah cenderung menjadi ateis, sementara agnostic tidak cenderung ateis, bahkan menimbulkan sikap rendah diri dan merasa tidak tahu segalanya, karena ada hal-hal yang harus diterima sebab keterbatasan ilmu akibat objek ilmu itu demikian rumit dan ghaib, tanpa harus meragukan ataupun mengingkarinya. Dengan demikian, menurutnya, bagi pandangan agnostic masih terbuka kemungkinan untuk menerima argumentasi dan karenanya tidak tertutup sebagaimana pandangan skeptic yang sudah menganggap tidak mungkin untuk mengetahuinya. ${ }^{15}$

Agnostisisme lahir pada abad ke-19, zaman setelah berlangsungnya aufklarung atau era pencerahan. Sejak zaman pencerahan dengan semboyan "sapere aude", yang berarti "berani berpikir sendiri atau beranilah mengambil keputusan sendiri" muncullah zaman bebas, merdeka, dan tidak lagi memerlukan kuasa apapun yang datang dari luar -selain dari dalam diri manusia sendiri. ${ }^{16}$ Persoalan "Tuhan" sebagai bagian metafistka pun ikut dipertanyakan. Penemuanpenemuan ilmiah secara bertahap menggugurkan statement-statemen gereja. Misalnya, teori evolusi organik

\footnotetext{
${ }^{15}$ Muhammad Mastury, "Agnostisisme dan Skeptisime...", hal. 91.

16 FX. Mudji Sutrisno dan F. Budi Hardiman (ed.), Para Filosof Penentu Gerak Zaman, (Yogyakarta: Kanisius, 1994), hal. 6263.
}

Darwin menggeser dogma gereja tentang peran "Tuhan" sebagai pencipta manusia. Menurut Darwin, makhluk hidup yang telah ada berjutajuta tahun lampau mengalami evolusi dan berkembang melalui kekuatan fisiko-kimia semata. ${ }^{17}$

Demikian pula konsep-konsep metafisika yang sekian lama menjadi dogma, dinilai tidak valid, tidak bisa diverifikasi, tidak konkrit, serta tidak positif di samping tidak fungsional. ${ }^{18}$ Lebih lanjut para filosof berusaha untuk membebaskan pengetahuan dari belenggu dogmatis ajaran kitab suci (Kristen). Antara lain Rene Descartes dengan rasionalismenya, David Hume dengan empirismenya serta Immanuel Kant dengan kritisismenya, memberi kejelasan-kejelasan baru tentang metafisika. Namun, meski Kant misalnya- telah menggugurkan bukti tentang "Tuhan" ala klasik (ontological, cosmological dan teological). ${ }^{19}$ dan menyebut hal itu sebagai nomena yang tidak terjangkau atau harus diterima adanya begitu saja (dengan rasio praktis), namun tidak memberi penjelasan yang cukup untuk mengungkap misteri tersebut. Bahkan penjelasannya itu adalah jawaban agnostic.

Ia (Tuhan) "ada" tetapi tidak bisa dibuktikan.secara empiris dan atau Ia "tidak ada" tetapi juga tidak bisa dibuktikan, dan inilah yang melahirkan skeptisisme. Membicarakan tentang sesuatu yang tidak berguna, adalah

17 Greg Sutomo, Sains dan Problem Ketuhanan, (Yogyakarta : Kanisius, 1995), hal.130.

18 Joko Siswanto, Sistem-sistem Metafisika Barat, (Yogyakarta, Pustaka Pelajar, 1998), hal. 1.

19 David Trueblood, Philosophy of Religion, terj. H. . Rasyidi, (Jakarta: Bulan Bintang, 1965), hal. 49-52. 
sama sekali tidak ilmiah dan juga karena itu tidak bermanfaat. Akibatnya, pertanyaan-pertanyaan ilmu pengetahuan tentang alam raya (di luar "Tuhan") terus menerus dijawab secara ilmiah tanpa sedikitpun melibatkan "Tuhan" di dalamnya.

\section{Akar Agnostisisme Modern}

Agnostisisme tumbuh dari aliran-aliran filsafat yang berkembang saat itu, terutama berakar dari empirisme Hume, kritisisme Kant, serta positivisme Comte. Menurut Mudji Sutrisno, Hume dianggap sebagai puncak empirisme disamping seorang. penganut skeptisisme modern. Skeptisisme Hume menyimpulkan bahwa ilmu pengetahuan dan filsafat tidak mampu menciptakan kepastian dan tidak pernah melebihi taraf probabilitas. $^{20}$

Keterkaitan antara akar agnostisisme dengan empirisme Hume tampak dari penjelasan Hume bahwa pengetahuan timbul dari pengalaman yang murni dan karenanya hanya terdiri dari komparasi dan asosiasi dari ide-ide. Sebab itu, yang dapat diketahui hanyalah ide kita sendiri dan hubungan antara ide-ide itu. Sedangkan apa-apa yang bersangkutan dengan ide dan hubungan dengan itu sendiri tidak diketahui secara empiris. $^{21}$ Prinsip kausalitas yang memberi kesimpulan asosiasi-asosiasi tentang hubungan ide, dengan sendirinya gugur sebab bukan berasal dari empirik. Demikian juga ide bawaan dan substansi Descartes ditentang oleh Hume. Itulah sebabnya,

20 F.X. Mudji Sutrisno, dan F. Budi Hardiman (ed.), Para Filosof Penentu..., hal. 62.

${ }^{21}$ Louis O. Kattsoff, Pengantar Filsafat, alih bahasa Soejono Aoemargono, (Yogyakarta: Tiara Wacana, 1996), hal. 151. ide tentang Allah karena tidak berasal dari empirik, adalah sama sekali tanpa makna.

Sedangkan terkait dengan kritisisme Kant, tampak dari konsep tentang tiga ide transendental, yakni ide jiwa, ide dunia dan ide tentang "Tuhan", dipandang bersifat apriori dan tidak berasal dari pengalaman. Ide itu ada begitu saja, mengatasi fenomena, sehingga sama-sekali tidak mempunyai pengetahuan teoritis tentangnya. Konsep tentang itu dipandang tidak lebih dari sebuah kepercayaan yang justru harus diadakan sebelumnya. ${ }^{22}$ Dari sisi ini, Kant bisa disebut sebagai seorang agnostik. $^{23}$

Akar agnostisisme modern juga terkait dengan positivisme Comte. Positivisme merupakan penerapan empirisme. Ia membatasi pengetahuan atas fakta yang dapat diamati, serta hubungan-hubungan antara fakta tersebut. Karena itu positivisme menolak setiap bentuk metafisika yamg berdasar pada apriori dan prinsip-prinsip normatif. Sains positif menurut Comte memiliki ciri-citi nyata, berguna, pasti, terperinci, organik serta nisbi. ${ }^{24}$ Periode metafisika -menurut Comte- adalah periode kedua setelah periode teologi.

\footnotetext{
22 Joko Siswanto, Sistem-sistem Metafisika..., hal. 67.

23 Timothy Fitzgerald, "Mansel's Agnosticism" dalam Religius Study, Nomor 26 Tahun 1990, hal. 528-529.

24 Dick Hartoko, Kamus Populer

Filsafat, (Jakarta: Rajawali, 1986), h. 83-84. Dalam perkembangannya positivisme logis dengan prinsip verifikasi sistemik dan analitik memandang proposisi metafisika menjadi tidak bermakna. "A statement which is no relevant to any experience has no factual content". Lihat A.J. Ayer, Language, Thruth and Logic, (London: Victor Gollancs, Ltd., 1952), hal. 556.
} 
Sedangkan periode terakhir dan tertinggi adalah periode. positifistik, yakni periode penyelidikan ilmiah yang bertumpu pada fakta yang terukur dan teramati. ${ }^{25}$

Dari ketiga aliran, yakni empirisme Hume, kritisisme Kant, dan positivism Comte ini tampak bahwa meski mereka berbicara dan memberi penjelasan tentang "Tuhan"dengan alasan baru (berbeda dengan dogma yang telah usang), namun "Tuhan" dalam perspektif ini tetap sebagai misteri yang tidak bisa ditelusuri lebih lanjut secara filosofis dan ilmu pengetahuan. Bagi penganut Agnostisisme, hal tersebut merupakan "bukti" bahwa memang manusia tidak memiliki pengetahuan apa-apa tentang "Tuhan", baik untuk memberikan pembenaran ataupun membantah keberadaannya.

\section{AGNOSTISISME DAN SAIN}

Metodologi dan pendekatan filosofi agnostisisme, yang berakar pada empirisme dan positivisme, merupakan penerapan model epistemologi empirik Natural Sciences. Model ini, dalam langkah progresifnya, menempuh jalan observasi, eksperimentasi, dan komparasi. Keberhasilan dan kebenaran ilmiah diukur secara positivistik, dalam arti yang benar dan yang nyata haruslah kongkrit, eksak, akurat dan memberi kemanfaatan. ${ }^{26}$

${ }^{25}$ Harold H. Titus, Persoalan-persoalan Filsafat, Alih Bahasa, H.M. Rasjidi, (Jakarta: Bulan Bintang, 1984), hal. 364-5.

${ }^{26}$ Akibat yang muncul menurut Koento Wibisono, adalah dimensi-dimensi kehidupan yang abstrak, kualitatif menjadi terabaikan dan terlepas dari pengamatan. Lihat Koento Wibisono Siswomihardjo, Hubungan Filsafat, Ilmu Pengetahuan, dan Budaya, Makalah Tidak Diterbitkan, hal. 7.
Metode ini oleh kaum agnostis diterapkan kepada persoalanpersoalan yang terkait dengan metafisika, yakni sesuatu yang berada di luar fisika.

Nataniel Micklem, dalam karyanya A Religion for Agnostic, memulai chapter pertama dengan "Science Must be Atheist". Ia menjelaskan maksudaya, "that the. existence or Being of God is not a question relevant to scientific studies". 27

enurut Micklem, intervensi "divine" atas ilmu pengatahuan mengakibatkan perkembangan ilmu pengetahuan menjadi lamban. Ilmu pengetahuan (sciences) memerlukan penjelasan ilmiah dan untuk itu dilakukan observasi tanpa batas, sehingga ilmu pengetahuan terus berkembang menuju penemuanpenemuan baru berikutnya. Sesuatu yang tidak terjelaskan secara ilmu pengetahuan, karena tidak terjangkau, dengan sendirinya akan ditinggalkan. Persoalan "Tuhan" tetap tinggal sebagai persoalan misteri. Penjelasan dengan wahyu bukanlah wilayah sains. Penjelasan secara wahyu sebagai statement dari langit, tempat "Tuhan" sendiri berada dengan sendirinya tidak dapat diterima. "God of scientist is not the God of the prophet, priest or moralist". ${ }^{28}$

Dalam pandangan ini, bagi seorang saintis (fisikawan, kimiawan, dsb), dalam observasi dan eksplorasi

27 Nathaniel Micklem, A Religion for Agnostisisc, (London: SCM Press Ltd, 1965), hal. 17.

28 Sidney Hook, "Modern Knowledge and the Concept of God" dalam Peter Angeles (ed.), Critiques of God, A Major Statement of the Case Against Belief in God, (New York: Prometheus Book, 1976), hal. 108-10. 
ilmiahnya tidak patut untuk melibatkan campur tangan "Tuhan". Pernyataan bahwa sesuatu itu terjadi karena kehendak atau kekuasaan "Tuhan", akan menghentikan ekplorasinya lebih lanjut dan dengan demikian ilmu pengetahuau akan mengalami kemandegan. "He has done nothing whatever to elucidate the mystery". Padahal dalam dunia ilmiah, penemuan sesuatu tidak bisa dikatakan mencapai final, tapi hanya sekedar penangguhan untuk mencapai penemuan-penemuan berikutnya.

Meskipun demikian, sejatinya pandangan agnostik ini bisa dibantah dengan argumentasi bahwa alam sebagal objek eksplorasi dan observasi harus berangakat dari proses "berawal" dan "berak hir". Sains dalam konteks ini tidak dapat menjelaskan proses tersebut, sebagaimana juga teologi tidak mampu memberi "penjelasan". Hal yang paling mudah dan sederhana adalah mengatakah bahwa "Tuhan" mengadakannya dari ketiadaan dan akan mengakhirinya menjadi ketiadaan, sesuatu misteri yang tidak mungkin dijelaskan lebih lanjut. ${ }^{29}$ Darwin sendiri menyebut bahwa ia tidak dapat memecahkan misteri awal kehidupan. $^{30}$

Menyebut bahwa "Tuhan" sebagai created and will reduce 'it (universe), berartt telah menolak atheisme. Namun untuk menjelaskan "apa dan bagaimana" Ia, juga merupakan persoalan di luar sains. Jalan tengah adalah agnostisisme. Bila theism berangkat dari provable dan atheism dari disprovable, maka agnostisisme

29 Nathaniel Micklem, A Religion for Agnostisisc..., hal. 29.

${ }^{30}$ Vide Hans Kung, Does God Exist?, an Answer for Today, (New York: Doubleday, 1980), hal. 348. menempati posisi yang tidak ikut serta dalam perbincangan intelektual tentang itu. $^{31}$ Persoalan pelik dan saling memberi "argumentasi" tentang ada atau tiadaNya -yang sesungguhnya tidak dapat dibuktikan secara sains baik "benar" atau "salah"-nya, tampaknya oleh penganut aliran ini "diselesaikan" oleh alternatif yang lebih "rasional" yakni agnostisisme. ${ }^{32}$

\section{KESIMPULAN}

Di antara kekeliruan berfikir adalah meletakkan semua pada kekuatan pikiran, sementara pada saat yang sama diakui pula bahwa akal pikiran memiliki keterbatasanketerbatasan. Relativitas yang dimiliki oleh inderawi dan juga oleh akal, mestinya tidak serta merta menegasikan sesuatu yang memang tidak tercandra oleh indera. Banyak fenomena dimana akal bisa dan bahkan harus menerima eksistensi sesuatu, meskipun indera tidak mampu untuk membuktikannya secara empiris.

Dalam konteks inilah antara lain agama dibutuhkan untuk memberi jawaban. Keimanan, kepercayaan, atau credo sangat diperlukan untuk menjawab pertanyaan yang tidak bisa diselesaikan sain melalui positivisme dan empirisme. Persoalan eskatologis misalnya, yang semua agama membicarakannya, tidak bisa dijelaskan oleh saintis. Padahal persoalan ini menjadi misteri yang sangat menggelisahkan jiwa manusia, dan butuh jawaban yang "pasti". Agama lah yang menjawabnya dengan

${ }^{31}$ Michael Schriven, "God and Reason" dalam Peter A. Angeles, Dictionary of Philosophy..., hal.108-10.

32 Clemen Dore, "Agnosticism" dalam Religious Study, Nomor 18 Tabun 1982, hal. 507. 
sistem kepercayaan, keyakinan, atau lebih dikenal dengan iman. Karenanya, hal-hal yang bisa diindera dengan terang benderang, barangkali tidak memerlukan "keimanan". Tuhan, dalam konteks ini adalah wilayah keimanan, bukan wilayah sain. Di sinilah tampak "kekeliruan" aliran agnostisisme.

\section{DAFTAR KEPUSTAKAAN}

Ayer,A, J., Language, Thruth and Logic, London: Victor Gollancs, Ltd., 1952.

Angeles, Peter A., Dictionary of Philosophy, New York: Bames \& Noble Book, 1981.

Armstrong, Karen, A History of God, The 4000- Year Quest of Judaism, Christianity and Islam, New York: Alfred A. Knopf, 1993.

Dore, Clemen, "Agnosticism" dalam Religious Study, Nomor 18 Tabun 1982.

Fitzgerald, Timothy, "Mansel's Agnosticism" dalam Religius Study, Nomor 26 Tahun 1990.

Hardon, SJ, Vide John A., Pocket Chatolik Dictionary, New York: A Division of Doubledaya and Company Inc., 1985.

Hartoko, Dick, Kamus Populer Filsafat, Jakarta: Rajawali, 1986

Hastings, James (ed.), Encyclopedia of Religion and Ethic, New, York: Charles Seribner's Sons, tt.

Hook, Sidney, "Modern Knowledge and the Concept of God" dalam Peter Angeles (ed.), Critiques of God, A Major Statement of the Case Against
Belief in God, New York: Prometheus Book, 1976.

https://id.wikipedia.org/wiki/Agnostisi sme

https://id.wikipedia.org/wiki/Thomas_ Henry_Huxley.

Huxley, Thomas Henry, "Agnosticism". The Popular Science Monthly, New York: D. Appleton \& Company, 1889.

Kattsoff, Louis O., Pengantar Filsafat, alih bahasa Soejono Aoemargono, Yogyakarta: Tiara Wacana, 1996.

Kung, Vide Hans,, Does God Exist?, an Answer for Today, New York: Doubleday, 1980.

Mastury, Muhammad, "Agnostisisme dan Skeptisime Suatu Analisis Perbandingan", dalam Jurnal Al-Jamiah No. 45 Th. 1991

Micklem, Nathaniel, A Religion for Agnostisisc, London: SCM Press Ltd, 1965.

Shinn, Roger L., "Agnostisisme" dalam George A. Cornish (ed.), Encyclopedia Americana, Internatimal Editio, New York : Americana Corporation, 1970.

Siswanto, Joko, Sistem-sistem Metafisika Barat, Yogyakarta, Pustaka Pelajar, 1998.

Siswomihardjo, Koento Wibisono, Hubungan Filsafat, Ilmu Pengetahuan, dan Budaya, Makalah Tidak Diterbitkan.

Sutomo, Greg, Sains dan Problem Ketuhanan, Yogyakarta: Kanisius, 1995.

Sutrisno, FX. Mudji dan F. Budi Hardiman (ed.), Para Filosof 
30 Majalah Ilmu Pengetahuan dan Pemikiran Keagamaan Tajdid,

Vol. 20, No. 1, Juli 2017

Penentu Gerak Zaman,

Yogyakarta: Kanisius, 1994.

Trueblood, David, Philosophy of Religion, terj. H. . Rasyidi, Jakarta: Bulan Bintang, 1965.

Tule, SVD, Romo Philipus. (ed), Kamus Filsafat, Bandung: Rosda Karya, 1995. 